\title{
Preservation of Pulai Wood (Alstonia scolaris L. Br.) with Natural Preservative Fruit Extracts Orania palindan (Blanco) Merr.
}

\author{
Endra Gunawan ${ }^{1}$ Edy Budiarso ${ }^{2}$ Enih Rosamah ${ }^{3}$ Enos Tangke Arung 3,* \\ ${ }^{1}$ Doctoral Program in Forestry Science, Mulawarman University, Jl. Ki Hajar Dewantara, Campus of Gn. Kelua Jl. \\ Penajam Samarinda 75119, East Kalimantan, Indonesia \\ ${ }^{2}$ Laboratorium of Wood Drying and Preservation, Faculty of Forestry, Mulawarman University, Jl.Penajam \\ Samarinda, East Kalimantan, Indonesia. 75119 \\ ${ }^{3}$ Laboratory of Forest Product Chemistry, Faculty of Forestry, Mulawarman University Campus of Gn. Kelua Jl. \\ Penajam Samarinda 75119, East Kalimantan, Indonesia \\ *Corresponding author.Email: tangkearung@yahoo.com
}

\begin{abstract}
Orania palindan is a betel species from the Arecaceae family which has a toxic content, especially in the fruit and tubers. This study aims to examine the ability of $O$. palindan fruit extract using room temperature water solvent $\left(27^{\circ} \mathrm{C}\right)$ and hot water $\left(100^{\circ} \mathrm{C}\right)$ as a natural preservative of pulai wood against fungus colonization of Tiromyces palustris and Coriolus. versicolor. The study was carried out using the gelatin culture block method. The data obtained from the experiment were analyzed using Completely Randomized Design (CRD) with the treatment of four concentrations of $O$. palindan extract and analyzed by Variance Analysis (ANOVA). Data is processed using the SPSS 22 for Windows application. The results showed that the impregnation test of pulai wood with $O$. palindan fruit extract tested using $T$. palustris showed that the treatment had lost their weight. The results showed that the impregnation test of pulai wood with fruit extract $O$. palindan tested using $C$. versicolor showed that the results also experienced a weight reduction. The analysis of variance, showed a significant effect of extract concentration treatment on weight loss of pulai wood due to colonization of T. palustris and $C$. versicolor, while the temperature treatment of extraction solvents, treatment of fungus types, and interactions between treatments was not significantly different. Based on the test results, the $O$. palindan as a natural preservative can be used to inhibit the reduction in weight of pulai wood due to the colonization of $T$. palustris and $C$. versicolor.
\end{abstract}

Keywords: Natural preservative, Pulai, Tiromyces palustris, Coriolus. Versicolor

\section{INTRODUCTION}

Papua Island is a region in Indonesia that has a high level of biodiversity. Globally, the Papua Island is also known to have a megadiversity because the number of its floras and faunas is estimated to reach up to 20,000 to 25,000 species. One of the richness of its floras is the betel nut (palms) of the Palmae or Arecaceae family [1]. The authors reported that up to 270 species of palms are founded in Papua and Papua New Guinea and many are believed to be discovered in the future. This number is discovered among 2,300 species globally and 1,000 species in Melanesia. Areca nut can also be found in many regions in India, Malaysia, Taiwan, Indonesia, and other countries in Asia.
As reported in Bhat et al [2] Areca nut is the fourth most commonly used social drug, ranking after nicotine, ethanol, and caffeine. It is estimated that over 600 million people recently use some form of areca nut worldwide, with the centers of heaviest use in Asia and the Western Pacific including those of Papua, Indonesia. There has no information yet on specific betel nut species that are consumed by Papuans, but one of the betel nut species that is not consumed by Papuan is from genera Orania. It is not edible due to the toxicity because the shoot part of this genera contains toxic components [1]. Furthermore, they stated that it is necessary to conduct a scientific study to test the toxic properties of the Orania plant as a natural preservative. 
Hence, this study aims to determine the natural preservative of extraction of Orania palindan using room temperature water's solvent $\left(27^{\circ} \mathrm{C}\right)$ and hot water $\left(100^{\circ} \mathrm{C}\right)$ to preserve pulai wood against the growth of wood decay fungi (Tiromyces palustris, Coriolus versicolor).

\section{MATERIALS AND METHODS}

\subsection{Sample Preparation}

Orania palindan fruits were collected in Demini Village of Momiwaren District, South Manokwari Regency in West Papua Province. The samples were collected from two trees. The samples were chopped into a size of $\pm 0,5 \mathrm{~cm} \times 0,5 \mathrm{~cm} \times 0,5 \mathrm{~cm}$ and dried in an air-conditioned room temperature between $22^{\circ} \mathrm{C}$ and $24^{\circ} \mathrm{C}$ until the samples reached the air-dried content. Then, the samples were crushed using a hammermill.

\subsection{Sample extraction}

500 grams of powder of the Orania palindan fruit produced using the hammermill then soaked in room temperature water $\left(27^{\circ} \mathrm{C}\right)$ and hot water $\left(100^{\circ} \mathrm{C}\right)$. The ratio between the powder and solvent was 1:5 and they were placed at room temperature for 24 hours. The extract filtrate was then evaporated at an air-conditioned room temperature between $22^{\circ} \mathrm{C}$ and $24^{\circ} \mathrm{C}$, and an electric fan was used to obtain a solid extract.

\subsection{Preparation and testing of fungi/fungus}

The modified culture block test method was used to test pulai wood preservatives of the extraction of $O$. palindan against $T$. palustris and $C$. Versicolor. The modification was made to test the sample in the size $2 \mathrm{~cm} \times 2 \mathrm{~cm} \times 6 \mathrm{~cm}$ [3]. The weight loss was calculated as:

Weight Lose: $\left[\left(b_{0}-b_{1}\right) / b_{0}\right] \times 100 \%$

\subsection{Statistical analysis}

The method for this study was an experimental method using a completely randomized design with four treatments $(0 \%, 2 \%, 4 \%$, and $6 \%)$ for three replications. The variable of the study was the $\mathrm{C}$. versicolor growth which was tested on a medium contains the extraction of $O$. palindan with a concentration of $2 \%, 4 \%$, and $6 \%$ based on the American Wood Preserve Association [4] (Standard No. M10-63).

\section{RESULTS AND DISCUSSION}

The effectiveness of the toxic components in $O$. palindan was examined by the weight reduction of pulai wood. results of the extract concentration and solvent temperature of $O$. palindan fruit extraction on the percentage of weight reduction of impregnated pulai wood with $O$. palindan fruit extract, which was colonized with $\mathrm{T}$. palustris, for room temperature solvent $\left(27^{\circ} \mathrm{C}\right)$ showed that the negative control treatment experienced an average weight reduction of $23.24 \%$, while treatment of $2 \%, 4 \%$, and $6 \%$ respectively decreased by $30.09 \% ; 26.50 \%$; and $10.95 \%$

Test results of extract concentration and temperature of $O$. palindan fruit extraction solvents on weight reduction percentage of impregnated Alstonia scolaris wood with tubers $O$. palindan extract, which were colonized with $C$. versicolor, for room temperature solvents $\left(27^{\circ} \mathrm{C}\right)$ showed that the negative control treatment-experienced flat the weight reduction was $27.01 \%$, while the treatment of $2 \%, 4 \%$ and $6 \%$ had a weight reduction of $27.26 \%$ respectively; $23.17 \%$; and $10.33 \%$

The results of LCMS analysis from the National Police Forensic Laboratory Center, on O. palindan fruit extracted with room temperature water $\left(27^{\circ} \mathrm{C}\right)$, contain which can prevent the growth of fungi. These compounds include methionine, dibutyl phthalate, norvaline, butamben, salsoline, and hexylamine. Salsoline is a toxic substance obtained from microorganisms, plants, and animals, which can interfere with the functioning of the nervous system of living creatures. Butamben is a compound that can be used as a neurological insecticide, Hexylamine is a compound that can cause acute poisoning if it enters the organism's body.

Whereas the O. palindan fruit extracted using hot water contains 2-Methoxybutanamide compounds. 3-isobutyl1H-1,2,4-triazol-5-amine, 4- (Diethylamino) benzoic acid, $\mathrm{N}$ - (3-Aminopropyl) -N-isopropylmethanesulfonamide, 3(1-Pyrrolidinyl) aniline, [4- (4-Methoxyphenyl) -2,2dimethyltetrahydro-2H-pyran-4-yl] acetic acid, and nicotine. 2-Methoxybutanamide has a derivative namely norvalin as a natural component of antifungal peptides and bacillus [5]. 3-Isobutyl-1H-1,2,4-triazole -5-amine is a compound used as an antibiotic material that effectively prevents bacterial attacks.

These toxic compounds can inhibit the metabolism of the two test fungi, so that the two fungi are not able to grow normally, thereby reducing the weathering process in pulai wood.

The results of LCMS analysis of $O$. palindan fruit extracted with room temperature water can be seen in Figure 1, while the $O$. palindan fruit dissolved in hot water can be seen in Figure 2 . 


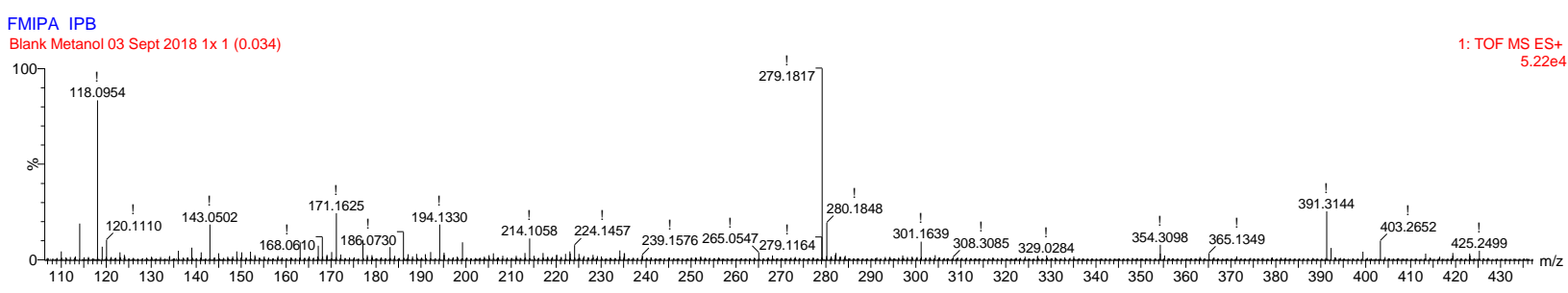

Figure 1 LCMS analysis results of $O$. palindan fruit extracted with room temperature water.

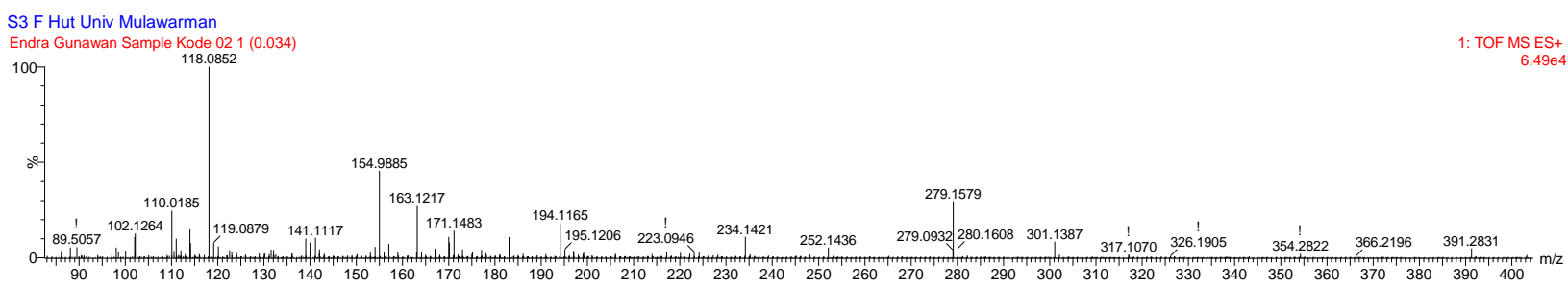

Figure 2 LCMS analysis results of $O$. palindan fruit extracted with hot water.

The results of the extract concentration and $O$. palindan fruit extraction solvent temperature on the percentage weight reduction of pulai wood impregnated with natural preservatives from fruit extracts of $O$. palindan, which were colonized with T. palustris, for hot water solvents $\left(100^{\circ} \mathrm{C}\right)$ showed that the negative control treatment experienced an average weight reduction of $23.24 \%$, while treatment $2 \%, 4 \%$, and $6 \%$ respectively experienced a weight reduction of $28.93 \%$; $11.80 \%$; and $7.46 \%$.

One factor that influences the extraction factor is the provision of temperature during the extraction process. Giving high temperatures will be able to remove compounds contained in an extract material so that the dissolved compounds can suppress the growth of fungi as an anti-fungus. The results of the research by Wulandari and Suhartatik [6] on the effect of heating temperature in the extraction of anthocyanin compounds of rosella flower petals (Hibiscus sabdariffa L.), stated that with increasing extraction temperature, the anthocyanin concentration increased. This is due to the increased temperature in extraction so that it will increase diffusivity in the extraction process so that the chemical component that is bound will also increase.

The results of research conducted by Hosseinihashmi et al [7] on the natural durability testing of beech (Fagus orientalis) wood experienced a weight loss ranging from $12 \%-30.20 \%$ due to $T$. versicolor attack (another name from $C$. versicolor) for 14 weeks of testing. Research conducted by Raoda [8] on natural durability testing carried out for three months on five types of wood (merbau, watergum, simpoer, gmelina, and pulai) with $C$. versicolor, average weight loss on merbau wood at $2.375 \%$, watergum at $19.047 \%$, simpoer is $26,962 \%$, gmelina is $28,493 \%$ and the highest decrease in weight is experienced in Pulai wood
$37,571 \%$. Based on the results of the above study, the weight loss that occurred in pulai wood for control treatment was lower than the results of research conducted by Raoda. This can be caused by the difference in the sample tree used, which is influenced by the factors of the place of growth, the age of the tree, the part of the plant taken, and other factors.

Hosseinihashmi et. al. [7], states that $C$. versicolor is capable of damaging cell walls by integrating cellulose, lignin, and hemicellulose for needle leaf type wood. Antai and Crawford [8] state that in general Brown-rot like Poria placenta prefers to attack needle wood (softwood) rather than hardwood (hardwood). while white-rot, such as $C$. versicolor decomposes both lignin and carbohydrate components in softwood and hardwood. Pulai wood is a type that belongs to the group of wide leaf wood so that it does not experience a higher degradation process than the degradation carried out by $T$. palustris fungi.

The results of variance analysis, extract testing, and solvent extraction temperature of $O$. palindan fruit as a natural preservative of pulai wood against $T$. palustris and $C$. versicolor, showed that there was a significant effect of extract concentration treatment on weight loss of pulai wood due to colonization of $T$. palustris and $C$. versicolor, while the extraction solvent temperature treatment, fungal type treatment, and interactions between treatments were not significantly different.

The results of the analysis of variance, the effect of extract concentration and solvent extraction temperature of $O$. palindan fruit on the average percentage of weight loss of impregnated woody pear fruit extracts of $O$. palindan fruit as a natural preservative due to colonization of T. palustris and C. versicolor, showed that there the real treatment of extract concentration on weight loss of pulai wood due to the colonization of $T$. 
palustris and $\mathrm{C}$. versicolor, while the treatment of extraction solvent temperature, treatment of fungus types, and interactions between treatments was not significantly different.

The test results showed that the concentration treatment had a significant effect on the percentage of weight loss of pulai wood which was given O. palindan fruit extract due to colonization of $\mathrm{T}$. palustris and $\mathrm{C}$. versicolor so that further testing was necessary.

Tukey's further test results with confidence level 95, the effect of O. palindan fruit extract concentration on percent weight loss of pulai wood impregnated with natural preservatives from fruit extracts of $\mathrm{O}$. palindan due to colonization of T. palustris and C. versicolor can be seen in Table 1 .

Table 1. Tukey Test with Trust Level 95, Effect of Concentration of O. palindan Fruit Extract on Percent of Weight Loss on Impregnated Pulai Wood with Natural Preservatives due to colonization of T. palustris and C. versicolor

\begin{tabular}{|c|c|c|c|c|}
\hline \multirow{2}{*}{ Concentration } & \multirow{2}{*}{$\mathrm{N}$} & \multicolumn{3}{|c|}{ Subset } \\
\hline & & 1 & 2 & 3 \\
\hline $6 \%$ & 12 & 2.9342 & & \\
\hline $4 \%$ & 12 & & 4.3583 & \\
\hline 0 (Control) & 12 & & & 5.0433 \\
\hline $2 \%$ & 12 & & & 5.2592 \\
\hline Sig. & & 1.000 & 1.000 & .802 \\
\hline
\end{tabular}

$$
\text { b. Alpha }=.05 \text {. }
$$

Tukey test results as listed in table 1 show that the negative control treatment was not different from the $2 \%$ treatment, but both of these treatments differed from the treatment of $4 \%$ and $6 \%$. Tukey test results also showed that the concentration treatment was $4 \%$ different from the $6 \%$ concentration treatment. Based on the results of the test, in use as a natural preservative (antifungal) to inhibit percent reduction in weight of pulai wood due to colonization of T. palustris and $C$. versicolor can use a concentration of $4 \%$, but if desired optimal results can be used even higher concentrations.

The results of the analysis of the various effects of extraction solvent temperature and fungus temperature on the percentage of weight loss of pulai wood can be seen in Tables 2 and 3.

Table 2. Results of Variance Analysis Effect of Extraction Solvent Temperature on Weight Loss Percentage of Pulai Wood

\begin{tabular}{lrrrr}
\hline Temperature & Mean & Std. Error & \multicolumn{2}{c}{$\begin{array}{c}\text { 95\% Confidence Interval } \\
\text { Upper Bound }\end{array}$} \\
\hline 27 & & Lower Bound & 4.912 \\
100 & 4.670 & .119 & 4.427 & 4.370 \\
\hline
\end{tabular}

The results of testing the effect of extraction solvent temperature showed that the fruit extract dissolved with a solvent temperature of $100^{\circ} \mathrm{C}$ gave an average weight reduction lower than impregnated wood using a room temperature extract $\left(27^{\circ} \mathrm{C}\right)$ so that in use it was necessary to extract the heating treatment.

Table 3. Results of Variance Analysis of the Effect of Fungus Type Treatment on Weight Loss Percentage of Pulai Wood

\begin{tabular}{lrrrr}
\hline Fungus & Mean & Std. Error & \multicolumn{2}{c}{ 95\% Confidence Interval } \\
& & & Lower Bound & Upper Bound \\
\hline T.palustris & 4.429 & .119 & 4.187 & 4.672 \\
C. versicolor & 4.368 & .119 & 4.126 & 4.611 \\
\hline
\end{tabular}


The test results showed that T. palustris caused a decrease in the weight of pulai wood than C. versicolor in extraction using O. palindan fruit. This is due to the presence of tannin in O. palindan fruit extract which can inhibit wood degradation by $C$. versicolor. Phytochemical test results obtained that in the fruit section $O$. palindan contains tannins and alkaloids. This result is in line with the research of Jelokova and Sindeler (1997) cited by Hosseinihashemi et al. [8], reported that the presence of tannins as phenolic compounds can increase the durability of beech wood against T. versicolor (C. versicolor), Serpula lacrymans, and mold further stated that phenolic components in a plant function as a protective compound from pathogenic attacks.

\section{CONCLUSION}

Based on the research it can be concluded:

1. O. palindan fruit extract contains toxic compounds, such as butamben, salsoline and hexylamine, which can inhibit the growth of $C$. versicolor and $\mathrm{T}$. palustris in the process of degradation of Pulai wood

2. The durability of Pulai wood from class does not stand to be very resistant by using $6 \%$ concentration extract.

3. The extraction process using hot water produces extracts that have higher inhibitory power than using cold water.

\section{ACKNOWLEDGMENTS}

We Thank Mr. Azhar for the LCMS analysis.

\section{REFERENCES}

[1] W. Wardana, Evaluation of soil potention and vegetation biomass in reclamation area of PT. Kaltim Prima Coal. Sengata. East Kutai. Thesis. Universitas Mulawarman, Samarinda, Indonesia, 2008. [Indonesian]

[2] W.J. Baker, J. Dransfield, Palem New Guinea. Royal Botanic Garden, KEW, 2006.

[3] S.J.S. Bath, M.D. Blank, R.L. Blaster, M. Nichter, M. Nichter, Areca Nut Dependence Among Chewers in a South India Community Who Do Not Also Use Tobacco. Addiction. 2010;105(7):13031310 .

[4] G.M. Hunt, G.A. Garratt, Wood Preservation. The American Series. McGraw-Hill Book Co, Inc. New York, 1953.

[5] ASTM D2017-05. Standard Test Method of Accelerated Laboratory Test of Natural Decay Resistance of Woods (Withdrawn 2014).
[6] Pubchem.

https://pubchem.ncbi.nlm.nih.gov/compound/butam be. Accessed on 15 October 2018.

[7] W.Y. Wulandari, Suhartatik, Pengaruh Suhu Pemanasan dan Ukuran Mesh dalam Ekstrasi Senyawa Antosianin Kelopak Bunga Rosela (Hibiscus sabdariffa L.), 2013;26(1). [Indonesian]

[8] S.K. Hosseinihashmi, M.Z.M. Salem, S.K.H, Ashrafi, A.J. Latibari, Chemical Choposition and Antioxidant Activity of Extract from the Wood of Fungus Orientalis: Water Resistance and Decaay Againts Trametes versicolor. BioResouses. 2016;11(2):3890-2899.

[9] Raoda, Pengujian Keawetan Alami Lima Jenis Kayu Terhadap Serangan Cendawan Pelapuk Kayu Tyromyces palustris dan Coriolus versicolor. Skipsi Program Sarjana Jurusan Budidaya Hutan Universitas Negeri Papua. Manokwari, 2006. (unpublished). [Indonesian]

[10] S.P. Antai, D.L. Crawford, Degradation of Extractive-Free Ligocellulosa by Coriolus versicolor and Poria placenta. European Journal of Applied Microbiol Biotecnol Springer Verlag, 1982, pp. $165-168$. 